\title{
GCU
}

Glasgow Caledonian

University

University for the Common Good

\section{Community off-sales provision and the presence of alcohol-related detritus in residential neighbourhoods}

Forsyth, Alasdair; Davidson, Neil

Published in:

Health and Place

DOI:

10.1016/j.healthplace.2009.11.003

Publication date:

2010

Document Version

Author accepted manuscript

Link to publication in ResearchOnline

Citation for published version (Harvard):

Forsyth, A \& Davidson, N 2010, 'Community off-sales provision and the presence of alcohol-related detritus in residential neighbourhoods', Health and Place, vol. 16, no. 2, pp. 349-358.

https://doi.org/10.1016/j.healthplace.2009.11.003

\section{General rights}

Copyright and moral rights for the publications made accessible in the public portal are retained by the authors and/or other copyright owners and it is a condition of accessing publications that users recognise and abide by the legal requirements associated with these rights.

Take down policy

If you believe that this document breaches copyright please view our takedown policy at https://edshare.gcu.ac.uk/id/eprint/5179 for details of how to contact us. 


\title{
Community off-sales provision and the presence of alcohol-related
}

\author{
detritus in residential neighbourhoods
}

Alasdair J. M. Forsyth ${ }^{1} \&$ Neil Davidson ${ }^{2}$

Scottish Centre for Crime \& Justice Research

The Glasgow Centre for the Study of Violence

Glasgow Caledonian University

Cowcaddens Road

Glasgow

Scotland

G4 OBA

T. $+44(0) 1413318301$

F. +44 (0)1413313636

${ }^{1}$ Corresponding author.

${ }^{2}$ Now at the Scottish Institute for Policing Research, School of Social Sciences, University of Dundee, Dundee, Scotland DD1 4HN

The paper is based on research supported by the Alcohol Education Research Council (AERC) 'small grant' AP 05 / 0675 


\title{
Community off-sales provision and the presence of alcohol-related \\ detritus in residential neighbourhoods
}

\begin{abstract}
This paper investigates the relationship between community off-sales premises and alcoholrelated detritus (litter / remains) in residential neighbourhoods. This was accomplished by photographing all brand-identifiable alcohol product detritus (glass, packaging etc.) where they lay and mapping these against the presence of off-sales outlets (licensed convenience stores) in the community. It was hypothesised that alcohol-related detritus would be greatest near to such alcohol outlets. However, although there was some evidence of a 'broken bottles effect', accumulations of alcohol-related detritus near some off-sales premises, it is concluded that local area deprivation is a better predictor of such alcohol-related incivility than is outlet provision. The implications of these findings are discussed in relation to current social responsibility policy developments which are designed to make the alcohol industry liable for alcohol-related incivilities.
\end{abstract}

Key words alcohol, overprovision, deprivation, litter, glassware

Word Count 4,982

Acknowledgment The authors would like to thank Ellie Bates of the School of Law, University of Edinburgh, Linda Bowie of Alcohol Focus Scotland and two anonymous reviewers for their helpful comments. 


\section{Introduction}

Since the turn of the millennium, across the UK and elsewhere, there has been growing concern about levels of alcohol-related incivility / anti-social behaviour ('binge drinking') and how licensing law should respond to these (Academy of Medical Sciences, 2004; Engineer et al, 2004; Gardham, 2007; Jarvinen \& Room, 2007; Martinic \& Measham, 2008; 'Nicholson Committee Report', 2004; Prime Minister's Strategy Unit, 2004). Initially these concerns were directed towards alcohol-related disorder associated with on-trade licensed premises, particularly those of the Night-Time Economy located in central places, rather than towards off-sales or residential neighbourhoods or daytime hours (Brown, 2004; Forsyth et al, 2005; Hetherington, 2004; Purves, 2004). Consequently it has been noted, that to date there has been a paucity of research into community off-sales and alcohol-related incivility in residential neighbourhoods (Human Factors Analysts Limited, 2007; Jayne et al, 2006). For example, Pattoni et al (2007, p30) noted that "A large amount of research has been conducted on the selling of alcohol in pubs and clubs, along with a considerable amount of work on violence and disorder and its relationship with alcohol. However, investigations of the exact connections between where alcohol is purchased in the community setting and the effects are limited."

This research addresses the above shortcoming directly at time when both the media and legislators are turning their attention towards the off-sales sector (Bolger, 2008; British Liver Trust, 2008; Eley, 2008; Currie, 2007; Gardham, 2008; Gray, 2008). Specifically outlets licensed for the sale of alcohol to be consumed off premises only. Additionally there is some debate over how blame should be apportioned within the off-sales sector, between small local community outlets and the major superstores, (Beers, 2008; Evening Times, 2008; Musson, 2008; The Scottish Government, 2007; Swanson, 2008). 
There are number of arguments suggesting that off-sales outlets have the potential to cause a greater level of alcohol-related harm in the community than on-trade outlets such as pubs or clubs. These include off-sales prices tending to be cheaper (BBPA, 2007; Blunden, 2007; Campaign for Real Ale, 2007; Godfrey, 2007; Withrington, 2007), that off-sales outlets are the main source of alcohol consumed by younger under-age drinkers, whether purchased directly or via third party adult agents (Boreham \& McManus, 2003; Bradshaw, 2003; Forsyth \& Barnard, 2000; Toomey et al, 2004; Willner et al, 2000) and that off-sales purchases can involve very large amounts of alcohol being purchased with no control over who actually drinks it, where, or the consequences of this consumption (Galloway et al, 2006; Human Factors Analysts Limited, 2007). By way of contrast, on-trade purchases involve measured doses with consumption being continually monitored by serving staff in an enclosed environment (Forsyth et al, 2005; Graham et al, 2005).

As well as their physical location, local community off-sales premises are particularly vulnerable to accusations of blame for alcohol-related incivility in residential areas. The alcohol products sold by some community off-licenses are those which have been identified as encouraging immodest consumption, such as super-lagers, white ciders, tonic wine and other fortified beverages (Brain \& Parker, 1997; Forsyth et al, 1997; Galloway et al, 2006; Harrington, 2008; Hughes et al, 1997; Swanson, 2008). For example, a Scottish Government report claimed that "Very often the stock carried by 'suspect' premises and the way it is marketed is quite clearly aimed at youngsters with cheap, fortified wines, strong cider and 'alcopops' being very much to the fore" and "[in a former coal mining community] Ministers were told to applause from the audience that 'off-licenses were the single largest contributory factor' [in anti-social behaviour]" ('Daniels Report', 2004, p17 and p2). In the extreme, there is some evidence that serious violent crime is more likely to be associated with off-sales alcohol 
consumption in residential areas, than in comparison to the more high profile alleged 'binge drinking' associated with city centre on-trade premises (Norstrom, 1998; Scribner et al, 1999).

The distribution of alcohol-related detritus (litter) in the community is an important feature of this neglected issue. As well as constituting a health and safety issue in its own right (e.g. glass injury), the presence of alcohol-related detritus is also indicative of other incivilities (e.g. 'street drinking', vandalism) that can make communities less attractive (valued) places in which to live, thus contributing to neighbourhood decline (Skogan, 1990) and reducing feelings of well-being among residents (Cummins et al, 1995). To combat such incivilities the Scottish Government has sought to introduce a Social Responsibility Levy (SRL) "to ensure alcohol retailers and licensed premises whose activities can impact negatively on the wider community contribute towards the cost of this impact" (Scottish Parliament, 2007, p.137).

An SRL makes alcohol outlets liable to pay a charge towards dealing with alcohol-related costs (e.g. policing, cleansing, transport etc.) based on principle commonly known as the "polluter pays' (Lehto, 1997, see also Beers, 2007; Bolger, 2008; Evening News, 2008; Gardham, 2008; Paisley, 2008; Wikipedia, retrieved 2009; Willmore, 2008). The SRL proposed by Scottish Government (2007) was initially attached to a 1998 Criminal Justice and Licensing Bill and was designed to make late-opening premises contribute to the extra costs of policing the nighttime economy. However, in line with the changing concerns detailed above, this was withdrawn in favour of attaching the SRL to a new Health Bill "broadened out to include offsales premises and the costs of other services" (Scottish Government, 2008. p.31). It is envisaged that this 'social responsibility fee' will be managed by local authorities (not central government) and that appropriate banding will take account of "alcohol turnover" rather than 
business size. This paper tests the applicability of such policy directly by investigating patterns of literal alcohol pollution relative to the presence of off-sales outlets.

\section{Methods}

\section{Selection of Study Area}

The fieldwork for this research was conducted in a Scottish town, hereafter named 'Middleburgh'. 'Middleburgh was chosen because it represented neither any extremes of ruralurbanisation, nor of affluence-deprivation. The town is defined by the Scottish Urban-Rural Classification system (Scottish Government, retrieved 2009a) as an "other urban area" (i.e. population between 10,000 and 125,000 ) and was located within commuting distance of a larger city. Similarly, the Scottish Index of Multiple Deprivation (SIMD) indicated that the town was not particularly deprived or affluent (Scottish Government, retrieved 2009b). The SIMD is calculated from seven domains; "income" (weighted at $28 \%$ of the total SIMD score), “employment" (28\%), "health" (14\%), "education" (14\%), "geographic access" (9\%), “crime” (5\%) and housing (2\%), each with their own sub-domains. For example, one of the seven indicators which make up the "health" domain is "hospital episodes related to alcohol use per person 2001-2004”.

Another reason for conducting this research in 'Middleburgh' was that it contained eight clearly defined post-war social housing developments ('schemes'), each with local off-sales provision. These 'schemes' are henceforth referred to collectively as the Study Area (population approximately 23,500, nearly half 'Middleburgh's' total) and individually as Neighbourhoods \#1 to \#8. Unless otherwise stated, housing throughout the Study Area uniformly consisted of low-rise housing units mixed in with walk-up flats (tenements). The 
main exceptions being that one Neighbourhood (\#7) was entirely low-rise and there were some high-rise apartments (in Neighbourhood's \#2 and \#4, but fewer than 10 such buildings in each).

The Study Area comprised 30 census Data Zones, which had mean population of 792 (SD = 122). These 30 Data Zones had a mean deprivation rank of 2,498 out of Scotland's 6,505 Zones $(S D=1,124)$ according to the SIMD. This figure is approximately $11 \%$ to the deprived side of SIMD mean. These 30 Data Zones are ranked from 1 to 30 for the purposes this paper (e.g. Data Zone-2 is the second most deprived). With the exception of one small pocket of deprivation (Data Zone-1, population rounded to 650) the Study Area did not include any neighbourhoods with extreme levels of either disadvantage or affluence. The 30 Data Zones comprising the Study Area had a mean "hospital episodes related to alcohol use per person" score of 0.0057 (range 0.0021 to 0.0124 ) which, although lower, did not differ significantly from the mean for all Data Zones in Scotland of 0.0076 (by independent $t$-test, $t=1.467, d f=$ 6503, $p=0.142$ ). This choice of Study Area was important as both alcohol problems and litter incivility are known to vary greatly between affluent and deprived areas (MacInytre et al 1993; Marmot, 1993), and had a more extreme Study Area been chosen then the research's findings may not have been viewed as being applicable elsewhere.

The Study Area contained 17 local shops, all of which functioned as convenience stores, with 13 of these being licensed to sell alcohol as off-sales premises. Being within planned social housing developments, these shops were not located in strips or parades along main roads but were individually sited amongst the housing at points where residents could easily access them on foot. This feature was important in the present research as it meant that the location of any alcohol-related detritus could easily be compared against an individual premise. Nevertheless, residents may choose to purchase alcohol and other goods elsewhere. With this in mind it was 
noteworthy that two (licensed) superstores were located in a non-residential part of 'Middleburgh'.

\section{Measuring the distribution of alcohol-related detritus}

Fieldwork involved the researchers conducting block assessments (Taylor et al, 1985), on foot, to observe and photograph any brand-identifiable alcohol-related detritus lying within all the residential public space of the Study Area. That is the streets and paths among the housing, but excluding parks, school playgrounds and internal stairwells (Forsyth \& Davidson 2009). Observations were conducted on week days between 25/06/07 and 13/07/07, during daytime hours (9.30AM to 5.30PM). Tracts of streets were surveyed each day, in turn, until the whole Study Area had been covered.

By using a digital camera it was possible to confirm that every item of detritus recorded was brand-identifiable as an alcohol product (i.e. photographic proof). This method also insured against double counts, and by the conclusion of fieldwork no photographed item's brand remained unidentified. It should be noted that for the purposes of this study, alcohol products are defined as drinks containing an $\mathrm{ABV}$ above $0.5 \%$, in accordance with the legal definition used in Scotland (Scottish Parliament, 2005).

The location of every item of detritus photographed was marked on a map in the field and its nature recorded (including beverage, brand and container type). This information was then entered into a quantitative data set along with data relating to its geographical location (including Neighbourhood, Data Zone and SIMD status). Bivariate (Independent $t$-tests) and multivariate (Linear Regressions) analyses were conducted on these data using the SPSS 
version 16 software package. It was hypothesised that alcohol-related detritus would be most concentrated in areas where an off-sales outlet was present.

\section{Results}

A total of 1,406 individual items of alcohol-related detritus were brand-identified from 1,239 photographs (some photographs contained more than one item of the same brand in the same shot, maximum of 10 items). The distribution of alcohol-related detritus was visually revealed by drawing eight maps, each corresponding to one of the Neighbourhoods ('schemes') which comprised the Study Area, plotting the location of every item of detritus against off-sales provision. Figures 1 to 3 are shown here as illustrative examples of the distributions found.

On each of these three figures (maps) the extent of the residential area (housing) is indicated by darker shading. Within this residential environment the locations of every item of detritus is denoted by a small spherical marker. When more than one item was found in the same location and recorded on a single photograph this is indicated by spheres which over-lap one another. Shops are indicated on each map by larger disc shapes, with black discs representing licensed shops, white discs unlicensed. As indicated on Figure 1, these maps also show Data Zone boundaries (with deprivation rank indicated as DZ-1 to DZ-30) and presence of any main (i.e. through) roads within each Neighbourhood. For reasons of anonymity precise geographical details are not shown and although the terms north, south, east and west will be used for orientation purposes, these may not be a reflection of their true co-ordinates.

$<$ Figure 1>

Figure 1 shows the distribution of the 67 items of alcohol-related detritus photographed in Neighbourhood \#1 which comprised the $23^{\text {rd }}, 26^{\text {th }}$ and $27^{\text {th }}$ most deprived of the 30 Data Zones 
in the Study Area. In this relatively less deprived Neighbourhood there were two shops, one sited in each of the two housing areas which made up this residential community, located on either side of a through road. Only three items of alcohol-related detritus were photographed immediately outside these shops. The main accumulation of alcohol-related detritus in this Neighbourhood was located well away from any shops, in Data Zone-27, to the east of Figure 1. This detritus was strewn along a fence and at a footbridge near to a bus-stop on the main road at the point where this highway leaves 'Middleburgh' heading towards the nearest city. The other accumulation in Figure 1 (seven over-lapping spheres) in the centre of Data Zone-23 consisted of a single photograph, a concrete 'honeycomb' wall with seven intact vodka bottles resting in / on it.

Figure 2 shows the distribution of the 258 items of alcohol-related detritus photographed in Neighbourhood \#2. This relatively mixed Neighbourhood comprised the $8^{\text {th }}, 12^{\text {th }}, 20^{\text {th }}, 24^{\text {th }}$, and $29^{\text {th }}$ most deprived Data Zones in the Study Area, as well as a small part of the $5^{\text {th }}$ most deprived Zone. This latter part Data Zone was shared with Neighbourhood \#4, which lay some distance away across a dual carriageway. Unusually this small area (DZ-5 [part] on Figure 2) was composed entirely of high-rise housing, 160 apartments including the tallest in the town. Here there was a particularly large concentration of alcohol-related detritus, which continued across the through road, over Data Zone-8 into Data Zone-12 (collectively an area of walk-up tenement style housing only, and the oldest part of the Study Area). As is shown by Figure 2, this mass of alcohol detritus was quite distant from any local shops.

$<$ Figure 2>

Neighbourhood \#2 had one licensed shop and two unlicensed. The unlicensed shops had no alcohol-related detritus directly outside them. In contrast, eight items were photographed 
directly outside the one licensed shop (not including another item inside the phone booth sited on this premise's forecourt). A similar number of items were located at an underpass / bus-stop on the nearby through road. Apart from these accumulations, large parts of Neighbourhood \#2 had no alcohol detritus, for example across Data Zones 24 and 29 (i.e. less deprived areas).

Figure 3 shows the distribution of the 579 items of alcohol-related detritus photographed in Neighbourhood \#3. This relatively deprived Neighbourhood comprised the $1^{\text {st }}, 2^{\text {nd }}, 3^{\text {rd }}, 4^{\text {th }}, 7^{\text {th }}$, $11^{\text {th }}$ and $13^{\text {th }}$, most deprived Data Zones in the Study Area plus most of Data Zone-9 (located to the west of Figure 3) which extended into Neighbourhood \#5. Neighbourhood \#3 had four shops, three of which were licensed. Near two of these shops were large accumulations of detritus, although neither of these premises had any detritus on their forecourts or otherwise directly outside. However, the unlicensed shop in this Neighbourhood had five items of alcohol-related detritus directly outside, plus an abandoned supermarket trolley (which was also photographed) bearing the logo of one of the two superstores in 'Middleburgh'. Neighbourhood \#3 was very much the closest in the Study Area to these superstores, both of which were situated directly across a main road from this residential area, to the east of Figure 3 (i.e. nearest to the two largest accumulations of detritus indicated on Figure 3).

\section{$<$ Figure 3>}

The amount of alcohol-related detritus photographed in this Neighbourhood was much greater than elsewhere in the Study Area. Although marginally the largest of the eight housing 'schemes', size alone would not seem to account for this Neighbourhood yielding $41.2 \%$ of all items of alcohol-related detritus, because available census data indicated that it only contained between 20.1 and $24.1 \%$ of the Study Area's population. This equates to a rate of between 101 and 121 items of alcohol-related detritus per 1,000 residents, compared to a maximum possible 
rate of 59 for the rest of the Study Area. No other neighbourhood had a rate greater than 69, the maximum possible rate of 'Neighbourhood \#4', which was second most deprived.

One possible explanation for the relative excess of alcohol-related detritus in Neighbourhood \#3 may be that it had the most licensed shops, three. However, three other Neighbourhoods had two licensed shops each, but much less detritus, with the rate per off-sales outlet in Neighbourhood \#3 being 193, compared with only 34, 77 and 46 in these other three Neighbourhoods (with the second most deprived Neighbourhood \#4 again having the second highest rate). Alternative, more plausible explanations for the over abundance of alcoholrelated detritus in this Neighbourhood may be its relatively greater levels of deprivation and perhaps also its proximity to 'Middleburgh's' two superstores. Various supermarket own-brand alcohol products were found throughout the Study Area $(n=21$, with 9 of the 18 items bearing the names of either superstore being photographed in Neighbourhood \#3). Items bearing other alcohol brand names were photographed both inside and beside abandoned superstore trolleys, as is illustrated by Plate 1 (photo taken in Neighbourhood \#3)

$<$ Plate 1>

The distribution patterns of alcohol-related detritus within the other five Neighbourhoods of the Study Area lay between those of Figures 2 and 3. These are summarised in Table 1, which breaks down the amount detritus photographed (including the number of glass items) by Neighbourhood, \#1 to \#8, and Data Zone, DZ-1 to DZ-30. Also shown on this table are SIMD deprivation ranks, local shopping provision (including off-sales status) and housing statistics (rounded to nearest 10 units).

<Table 1> 
Table 1 masks some micro-geographical variance in the distribution of detritus within the other five Neighbourhoods (\#4 to \#8), such as is illustrated elsewhere by Figures 1 to 3 . In these others there were also accumulations of detritus at underpasses or bus stops, and outside some shops. For example five items were photographed lying on the forecourt of the licensed shop in Data Zone-6, yet none was observed outside the licensed shop in Data Zone-28.

Figure 4 enters these data, relating to the number of items of alcohol-related detritus photographed, shown on Table 1, into a deprivation ranked bar-chart, which also indicates the shopping provision (off-sales status) across each of the 30 Data Zones of the Study Area.

\section{$<$ Figure 4>}

Figure 4, suggests that there is a relationship between this form of alcohol-related incivility and local (small area) deprivation (i.e. at census Data Zone level according to the SIMD 2006), but in regard to off-sales provision the picture is unclear. Data Zones with a licensed shop had a mean of 53.2 items, while Zones with no such off-sales provision had a mean of 42.0, a nonsignificant difference by independent t-test $(t=0.88, d f=20.35, p=0.385)$. In contrast, Zones in the relatively more deprived half of the Study Area (DZ-1 through 15) had a mean of 63.3 items of detritus per Zone compared with a mean of only 30.5 for Zones in the less deprived half $(t=3.14 . d f=24.96, \quad p=0.004)$. This relationship was confirmed by a regression equation in which, controlling for Data Zone population, deprivation rank but not the presence of an off-sales outlet predicted the number of items of alcohol-related detritus found. This is shown in Table 2, along with an alternative model which used the number of dwellings in the area of each Data Zone surveyed as a control variable instead of total Zone population.

$<$ Table 2> 
Figure 4 includes all items of alcohol-related detritus and takes no account of their hazardous potential. For example the total for Data Zone-13, which had the most items of detritus, included twelve plastic vodka miniatures (10 in a single photograph). To account for this relative level of hazard factor between types of alcohol-related detritus, the above analyses were repeated for glass items only $(n=587)$.

$<$ Figure 5>

Figure 5, shows the distribution of alcohol-related glass across the 30 Data Zones in the Study Area. An even sharper divide between the relatively deprived and less deprived halves of the Study Area is implied, but again there was no statistical difference between Zones which had a licensed shop and those which did not (means of 22.9 and 17.1 items of glassware respectively: $t=1.00, d f=21.56, p=0.328)$. Further, although Figure 5 indicates that the largest amount of glass was present in the only Data Zone to have two shops (DZ-5, one of which was licensed), from Table 1 it is noteworthy that most of this (or indeed most of any form of alcohol-related detritus) lay in the much smaller (high rise) part of this Zone, located in Neighbourhood \#2, where the was no shop. Data Zones in the more deprived half of the Study Area had significantly more glassware than those in the less deprived half, means of 28.5 and 10.8 items respectively $(t=3.89, d f=28, p=0.001)$. This pattern was confirmed in a regression equation, in which, controlling for Data Zone population (or number of dwellings), the amount of alcohol-related glassware lying in residential areas could be predicted by Data Zone deprivation rank, but not the presence of an off-sales outlet in the same model (see Table 2).

As can be seen from Table 2, the model predicting glass items from deprivation, controlling for outlet provision and population, was more robust and accounted for more of the variance (33.2\%) than that predicting any alcohol-related detritus (23.2\%). This was also true in the 
alternative model which controlled for extent of housing surveyed rather than total Data Zone population (31.7\% variance in glassware and $21.7 \%$ of all detritus explained).

\section{Discussion}

\section{Limitations}

The small scale of this project (total expenditure under £3k UK) necessarily limited its scope, and so raised several issues for future research to address. This research piloted the use of digital photography to record alcohol-related detritus. Indeed prior to the advent of such technology this visual method (VM) of data recording would not have been possible. During fieldwork the advantages of VM became clear. These data were not dependent on unverifiable self-reports (e.g. of the researchers), nor on the interpretation of statistics. All items recorded were confirmed as alcohol detritus and their location / setting and relationship to other features was verifiable. However this research did not use a Global Positioning System (GPS) camera. Since the application for funds for this research was made (2005), such technology has become more affordable. Using such GPS technology would have allowed instant analysis against existing data sets (e.g. SIMD) without the need for mapping.

The study was limited to social housing 'schemes' and it would have been interesting to compare these results with other environments, such as private housing developments, city centres, rural areas, parks etc. Also this research was conducted in one mid-sized town and it would be interesting to conduct a similar study in other towns, perhaps including those with a higher proportion of deprived areas. The study focused on alcohol detritus and not other refuse, though it was clear during fieldwork that these tended to co-exist. This is illustrated by Plate 2.

$<$ Plate $2>$ 
In Plate 2 the only brand identifiable alcohol-related detritus is a single bottle of MD 20/20 fruit-flavoured beverage, half hidden amongst a pile of refuse, which stretched for some distance farther than is indicated in the photograph, at the side of public steps directly in front of house (bathroom) windows, which made further investigation of this pile (one of three similar accumulations in this DZ-1) impossible for ethical reasons. Additionally at this location some items brand-identifiable detritus were observed but not photographed owing to their proximity to these windows and therefore not included in the data set (though these would have constituted less than one percent of all detritus). These limitations were only an issue during fieldwork in this the most deprived Data Zone in the Study Area, and without them the relationship found with deprivation (see Table 2) could only have been stronger.

Thus only observable alcohol-related detritus was measured, not that which was hidden under other refuse (as illustrated by Plate 2) or in semi-private locations (e.g. stairwells of high-rise blocks were not investigated). Nor were the contents of refuse receptacles investigated. With this in mind, it was noteworthy that accumulations of detritus were often in the same locations as fixed litter bins, particularly at bus-stops and some shop forecourts, and it is questionable whether providing extra receptacles would have any positive impact on this issue.

A related limitation was that the impact of Local Authority cleansing department activity could not be measured. In theory someone could have been cleaning up in front of the researchers as they surveyed, but equally so street drinkers could have been depositing alcohol refuse behind the researchers. Indeed, some items were photographed still draining alcohol, indicating very recent abandonment, while in contrast many others were clearly corroded (e.g. cans) or otherwise decayed indicating that they had lain in situ for some weeks. The survey was limited to weekday office hours. Although this policy is likely to have influenced the extent of alcohol- 
related detritus (e.g. there may have been more during the weekend at night, since swept-up), the same cannot so easily be said about the pattern of its distribution across residential areas. Similarly, seasonality is known to influence patterns of alfresco drinking (Galloway et al, 2007; Human Factors Analysts Limited, 2007). There were no major festive or sporting events coincident with this research, which took place during a period of extreme rainfall. Again, these limitations may have reduced the total amount of detritus observed, but should not have unduly affected its distribution pattern within residential areas, which is the focus of this paper.

\section{Implications}

Perhaps the most interesting finding was that, rather than outlet (over)provision, it was local levels of deprivation which governed alcohol-related detritus distribution, particularly so given that the Study Area did not represent extremes of affluence or disadvantage, and that this finding was more robust when only the most risky alcohol-related detritus (glass) was considered. Thus as well as acting as an indicator of deprivation, alcohol-related detritus can be seen as adding to the problems communities face, for example by posing an injury risk to residents (or their pets), preventing children from engaging in outdoor play, or by providing a potential source of weaponry in street violence (McKinlay et al, 2009, pp71-72.).

Though some shops did seem to display a 'broken bottles effect', having accumulations of alcohol-related detritus nearby, most accumulations of detritus were distant from these local shops. For example, there was a particularly impressive concentration of detritus distant for any shops which straddled two distinct housing areas, one of high-rises the other of tenement flats and it was noteworthy that, uniquely in the Study Area, here there was observably a lack of any ‘defensible space' (Newman, 1972). Similarly, bus-stops and underpasses often had accumulations of detritus. What these environments had in common with shop forecourts was 
the opportunity for loitering, a feature known to be conducive to street drinking (Galloway et al, 2007). As a shop sever interviewed during this research at one of the shops in Neighbourhood \#6 suggested, "Sometimes you can get about 25, 30 of them [street drinking youth] just wandering about all night long, moving from shop to shop" (Forsyth \& Davidson, 2008, p.79)

Items of alcohol-related detritus were photographed bearing the names of supermarkets not situated within the Study Area. Given that only a small proportion of superstores' alcohol shelf-space displays their own-brands, it is suggested that outlets operating outside the Study Area may have been responsible for much of the alcohol-related detritus photographed. The reach of the superstores was also evident during fieldwork by the presence of abandoned supermarket trolleys, which could themselves be associated with alcohol-related detritus. It was striking that there was an accumulation of alcohol-related detritus (and a supermarket trolley) lying directly outside an unlicensed local shop in the relatively deprived community closest to the two superstores operating in the town surveyed. Had that shop been licensed, it would have been easy to assume that here was the polluter who should pay (e.g. under the proposed 'social responsibility fee'.

Together these findings imply the near impossibility of attributing specific items of this (or for that matter any other any other form of) alcohol-related incivility to specific outlets. The same is likely to be true of on-trade outlets. For example practices such as pre-loading, circuitdrinking and after-parties (Forsyth 2009; Hughes et al, 2008) can involve patrons purchasing or consuming alcohol from several (types of) premises on a single occasion. Further, if the determining factor here is deprivation it may be unfair to penalise shops simply because they serve disadvantaged communities. Interviews with staff from the shops in the Study Area 
revealed that alcohol was usually their biggest seller, without which their other business (vital to some residents) would not be viable (Forsyth \& Davidson, 2008), making such marginal outlets particularly vulnerable to the proposed SRL legislation.

\section{Conclusion}

These findings highlight the need for future research investigating alcohol-related incivilities in the community to account for local levels of deprivation. This research implies that off-sales alcohol may not always be consumed near where it is purchased, and that local off-sales may end up shouldering the blame for problems originating elsewhere. The role that the major superstores may play in fostering in these should be investigated. Ultimately it is suggested that it is the type of drinker, rather than the type of outlet, that is the real polluter (see also Braiden, 2008; Massie, 2008). In this respect the incidence of alcohol-related detritus may be no different to any other physical incivility found in residential areas, as a marker for deprivation rather than an indicator of outlet overprovision. Thus it would seem more appropriate for policy-makers seeking to introduce an effective 'polluter pays' social responsibility levy to target the wider alcohol industry rather than individual retailers. 


\section{References}

Academy of Medical Sciences, 2004. Calling Time: The nation's drinking as a major health issue. London: The Academy of Medical Sciences. (Online) Available at:

http://www.acmedsci.ac.uk/images/project/CallingT.pdf. (Accessed: 07/10/09).

BBPA, 2007. Beer Duty Policy: A time for change. British Beer \& Pub Association, 2007 Budget Submission. (Online) Retrieved from: http://www.beerandpub.com/download.asp?id_Doc=2613. (Accessed: 2007).

Beers, R., 2007. Scotland faced paid-for policing. The Publican, September $5^{\text {th }}$.

Beers, R., 2008. Is it finally time to join forces with the "good" off trade? The Publican, August $28^{\text {th }}$.

Blunden, M., 2007. The Godfather of Binge-drinking: Tesco boss singled out for selling alcohol at rock bottom prices. Metro, December $7^{\text {th }}$.

Bolger, A., 2008. Scotland eyes tough rules on alcohol. Financial Times, March $5^{\text {th }}$.

Boreham, R. \& McManus, S., 2003. Smoking Drinking \& Drug Use among young people in England in 2002. London: The Stationary Office.

Bradshaw, P., 2003. Underage drinking and the illegal purchase of alcohol. Edinburgh: Scottish Executive Social Research. (Online) Available at: http://www.scotland.gov.uk/Resource/Doc/47032/0025168.pdf. (Accessed: 07/10/09)..

Braiden, G., 2008. Rethink on 'polluter pays' levies for pub and club owners. The Herald, December $8^{\text {th }}$.

Brain, K. \& Parker, H., 1997. Drinking with Design: Alcopops, designer drinks and youth culture. London: The Portman Group.

British Liver Trust, 2008. A Binge for the Cost of a Sandwich. (Online) Available at: http://www.britishlivertrust.org.uk/home/media-centre/campaigns/a-binge-for-the-cost-of-asandwich.aspx. (Accessed: 07/10/09).

Brown, C. (2004) Call for last orders on happy hour drinks. Scotsman, September $18^{\text {th }}$.

Campaign for Real Ale, 2007. Groceries Market Investigation - Emerging Thinking. Online letter to Competition Commission. (Online) Available at: http://www.competitioncommission.org.uk/inquiries/ref2006/grocery/pdf/responses_emerging thinking_third_party_n o_15.pdf. (Accessed: 07/10/09).

Cummins, S., Stafford, M., MacIntyre, S. Marmot, M., Ellaway, A., 2005. Neighbourhood environment and its association with self rated health: Evidence from Scotland and England. Journal of Epidemiology and Community Health, 59: 3, 207 - 213.

Currie, B., 2007. Cut-price Alcohol in Shops to be Outlawed: MacAskill vows to tackle culture of heavy drinking. Evening Times, September $5^{\text {th }}$. 
'Daniels Report', 2004. Off-sales in the Community. Edinburgh: Scottish Executive. (Online) Available at: http://www.scotland.gov.uk/Publications/2004/02/18764/31731. (Accessed: 07/10/09).

Eley, M., 2008. Retail chief: 'Supermarkets more responsible than pubs': Retail chief says a minimum price would unfairly punish majority of drinkers The Publican, November $10^{\text {th }}$.

Engineer, R., Phillips, A., Thompson, J. \& Nicholls, J., 2003. Drunk and Disorderly: A qualitative study of binge drinking among 18 to 24 years olds. Home Office Research Study No. 262. London: Home Office.

Evening News, 2008. Alcohol abuse: 'The polluter pays principle may be a help'. April $14^{\text {th }}$.

Evening Times, 2008. Supermarkets are not to blame. March $10^{\text {th }}$.

Forsyth, A. J. M., 2009. Front, Side and Back-loading: Reasons for drinking alcohol purchased off-premises before during and after attending nightclubs. Journal of Substance Use. DOI: 10.1080/14659890902966497.

Forsyth, A. J. M. \& Barnard, M., 2000. Preferred Drinking Locations of Scottish Adolescents, Health and Place, 6: 2, 105 - 115.

Forsyth, A. J. M., Cloonan, M. \& Barr, J., 2005. Factors associated with alcohol-related problems within licensed premises. Glasgow: Greater Glasgow NHS Board. (Online) Available at: $\quad$ http://www.nhsgg.org.uk/content/assetList.asp?aType=15\&aSType=184\&page=s16_2. (Accessed: 07/10/09).

Forsyth, A. J. M. \& Davidson, N., 2008. Passing The Buck? Are local licensed grocers to blame for alcohol-related incivility in residential communities? Scottish Journal of Criminal Justice Studies, 14: July, 63 - 95.

Forsyth A. J. M. \& Davidson, N., 2009. The nature and extent of Illegal Drug and Alcoholrelated Litter in a Scottish Social Housing Community: A photographic investigation. Addiction Research \& Theory. DOI: 10.1080/16066350802559464.

Galloway, J., Forsyth, A. J. M. \& Shewan, D., 2007. Young People's Street Drinking Behaviour: Investigating the influence of marketing \& subculture. London: Alcohol Education Research Council. (Online) Available at: http://www.aerc.org.uk/documents/pdfs/finalReports/AERC_FinalReport_0030.pdf. Accessed: 07/10/09).

Gardham, M., 2007. Boozing is our national sport. Daily Record, December $29^{\text {th }}$.

Gardham, M., 2008. A Bevvy Levy to beat ned Boozers: Shops targeted in blitz. Daily Record, February $13^{\text {th }}$.

Godfrey, C., 2007. Price, tax and alcohol problems. Presentation given at 'Scotch on the Rocks: How do we solve Scotland's drinks problem?' conference held at the Roxburghe Hotel, Charlotte Square, Edinburgh Scotland, May $11^{\text {th }}$. 
Graham, K., Jelly, J. \& Purcell, J., 2005. Training bar staff in preventing and managing aggression in licensed premises. Journal of Substance Use, 10: 1, 48 - 61.

Gray, A., 2008. Struggle to capture the stay at home drinkers. Financial Times, August $15^{\text {th }}$.

Harrington, J., 2008. Tory Alcopop Tax is Slammed: The Gin \& Vodka Association blasted Tory plans to treble tax on "alcopops" - because sales of the drink are in "significant decline". Morning Advertiser: The licensee's website, March $7^{\text {th }}$. (Online) Available at: http://www.morningadvertiser.co.uk/news_detail.aspx?articleid=58119. (Accessed: 07/10/09).

Hetherington, P. (2004) Time to be called on happy hours. The Guardian, Regional Affairs Editor, July $10^{\text {th }}$.

Hughes, K., MacKintosh, A., Hastings, G., Wheeler, C., Watson, J. \& Inglis, J., 1997. Young People, Alcohol and Designer Drinks: A quantitative and qualitative study. British Medical Journal, 314: $414-418$.

Hughes, K., Anderson, Z., Morleo, M. \& Bellis, M. A., 2008. Alcohol, nightlife and violence: the relative contributions of drinking before and during nights out to negative health and criminal justice outcomes. Addiction, 103: 1, 61 - 65

Human Factors Analysts Limited, 2007. The relationship between off-sales and problem drinking in Scotland. Edinburgh: Scottish Executive. (Online) Available at: http://www.scotland.gov.uk/Publications/2007/06/15155717/0. (Accessed: 07/10/09).

Jarvinen, M. \& Room, R., 2007. Youth Drinking Cultures: European Experiences. Aldershot: Ashgate.

Jayne, M., Holloway, S. L. \& Valentine, G., 2006. Drunk and disorderly, alcohol, urban life and public space. Progress in Human Geography, 30: 4, 451 - 468.

Lehto, J., 1997. The Economics of Alcohol. Addiction, 92: S2, S55 - S59.

MacIntyre, S., MacIver, S. \& Sooman, A., 1993. Area, Class and Health; Should we be focusing on places or people? Journal of Social Policy, 22: 2, 213 - 234.

Marmot, M., 1997. Inequality, deprivation and alcohol use. Addiction, 92: S1, S013 - S020.

Massie, A., 2008. Consumers, not retailers, of alcohol are the real polluters. Scotsman, February $14^{\text {th }}$.

McKinlay, W., Forsyth, A. J. M., Khan, F., 2009. Alcohol and Violence among Young Male Offenders in Scotland. SPS Occasional Paper No. 1 / 09. Edinburgh: Scottish Prison Service. (Online) Available at: http://www.sps.gov.uk/MultimediaGallery/80c8249a-3305-41b7-96ba970412a81c68.pdf. (Accessed: 07/10/09).

Musson, C., 2008. Supermarkets hit out at drink sales claims. Evening Times, March $7^{\text {th }}$. 
Newman, O., 1972. Defensible Space: Crime prevention through urban design. New York: Macmillan.

'Nicholson Committee Report', 2004. Review of Liquor Licensing Law in Scotland. Edinburgh: Scottish Executive. (Online) Available at: http://www.scotland.gov.uk/Publications/2004/03/19132/34937. (Accessed: 07/10/09).

Norstrom, T., 1998. Effects on criminal violence of different beverage types and private and public drinking. Addiction, 93: 5, 689-699.

Paisley, J., 2008. Carry-out tax could fund extra cops. Evening Times, February $12^{\text {th }}$.

Pattoni, L., Emmerson, C., Sudbery, M., MacDonald, R. \& Plunkett, M., 2007. The Relationship Between Off-Sales and Problem Drinking in Scotland: Literature review. Prepared by Human Factors Analysts Limited for Scottish Executive Social Research. Edinburgh: Scottish Executive. (Online) Available at:

http://www.scotland.gov.uk/Publications/2007/03/09092846/0. (Accessed: 07/10/09).

Prime Minister's Strategy Unit, 2004. Alcohol Harm Reduction Strategy for England (AHRSE). London: Strategy Unit. (Online) Available at: http://www.cabinetoffice.gov.uk/strategy/downloads/su/alcohol/pdf/CabOffce\%20AlcoholHar .pdf. (Accessed: 07/10/09).

Purves, L., 2004. It's Unhappy Hour in our Cities' Hangover Factories: No one would take their granny out to dinner these days, not with the clientele of the Lout \& Lapdancer likely to lurch in. The Times, June $8^{\text {th }}$.

Scottish Government, 2007. Licensing Act. September $24^{\text {th }}$. (Online) Available at: http://www.scotland.gov.uk/News/Releases/2007/09/24100116. (Accessed: 07/10/09).

Scottish Government, 2008. Changing Scotland's Relationship with Alcohol: A discussion paper on our strategic approach. (Online) Available at: http://www.scotland.gov.uk/Resource/Doc/227785/0061677.pdf. (Accessed: 07/10/09).

Scottish Government [online database] Scottish Executive Urban Rural Classification 20052006. $\quad$ Retrieved $\quad$ October $\quad 7 \quad 2009$ a from http://www.scotland.gov.uk/Publications/2006/07/31114822/9

Scottish Government [online database] Scottish Index of Multiple Deprivation. Retrieved October 7 2009b from http://www.scotland.gov.uk/Topics/Statistics/SIMD/

Scottish Parliament, 2005. Licensing (Scotland) Act 2005. (Online) Available at: http://www.scottish.parliament.uk/business/bills/pdfs/b37s2.pdf. (Accessed: 07/10/09).

Scottish Parliament, 2007. Criminal Justice and Licensing (Scotland) Bill. (Online) At: http://www.scottish.parliament.uk/s3/bills/24-CrimJustLc/b24s3-introd.pdf. (retrieved 2007).

Scribner, R., Cohen, D., Kaplan, S. \& Allen S. H., 1999. Alcohol Availability and Homicide in New Orleans: Conceptualised considerations for small area analysis of the effect of alcohol outlet density. Journal of Studies on Alcohol, 60: 3, 310 - 317. 
Skogan W. G., 1990. Disorder and decline: Crime and the spiral of decay in American neighbourhoods. New York: Free Press

Swanson, I., 2008. New blitz on cut-price booze. Evening News, March $22^{\text {nd }}$.

Taylor, R. B., Shumaker, S. A. \& Gottfredson, S. D., 1985. Neighborhood-level Links between Physical Features and Local Sentiments: Deterioration, fear of crime, and confidence. Journal of Architectural Planning and Research, 2: 4, 261 - 275.

Toomey, A. J., Wagenaar, A. C., Erickson, D. J., Fletcher, L. A., Patrek, W. \& Lenk, K. M., 2004. Illegal sales of alcohol to obviously intoxicated patrons at licensed establishments. Alcohol: Clinical \& Experimental Research, 28: 5, 769 - 774.

Wikipedia [Online dictionary]. Polluter pays principle. Retrieved October 72009 from http://en.wikipedia.org/wiki/Polluter_pays_principle

Willner, P., Hart, K., Binmore, J., Cavendish, M. \& Dunphy, E., 2000. Alcohol Sales to Underage Adolescents: An unobtrusive observational field study and evaluation of a police intervention. Addiction, 95: 9, 1373 - 1388.

Wilmore, J., 2008. Scots off-trade included in 'polluter pays' scheme. The Publican, February $13^{\text {th }}$.

Withrington, A., 2007. The Publican launches a campaign against supermarket prices. The Publican, April $19^{\text {th }}$. 
Table 1: Neighbourhoods, alcohol detritus, deprivation and off-sales provision

\begin{tabular}{|c|c|c|c|c|c|}
\hline $\begin{array}{l}\text { Neighbourhood (\#1 to } 8 \text { ) } \\
\text { Data Zone (DZ-1 to 30) }\end{array}$ & $\begin{array}{l}\text { Deprivation } \\
\text { score rank }\end{array}$ & $\begin{array}{l}N \text { items of } \\
\text { Detritus }\end{array}$ & $\begin{array}{l}\mathrm{N} \text { items } \\
\text { of glass }\end{array}$ & $\begin{array}{l}\text { Shops } \\
\text { (off-sales) }\end{array}$ & $\begin{array}{l}\text { Housing } \\
\text { ( } n \text { of houses and type) }\end{array}$ \\
\hline Total Neighbourhood \#1 & Mean 25.3 & Total 67 & 37 & $2(2)$ & \\
\hline Neighbourhood \#1 DZ-27 & $27^{\mathrm{a}}$ & 30 & 14 & $0(-)$ & 210: low-rise / walk-up \\
\hline Neighbourhood \#1 DZ-26 & 26 & 15 & 10 & $1(1)$ & 340: low-rise / walk-up \\
\hline Neighbourhood \#1 DZ-23 & 23 & 22 & 13 & $1(1)$ & 330: low-rise / walk-up \\
\hline Total Neighbourhood \#2 & Mean 18.6 ${ }^{b}$ & Total 258 & 116 & $3(1)$ & \\
\hline Neighbourhood \#2 DZ-20 & 20 & 69 & 31 & $1(1)$ & 380: low-rise / walk-up \\
\hline Neighbourhood \#2 DZ-29 & $29^{\mathrm{a}}$ & 29 & 15 & $0(-)$ & 350: low-rise / walk-up \\
\hline Neighbourhood \#2 DZ-24 & 24 & 9 & 3 & $1(0)$ & 310: low-rise / walk-up \\
\hline Neighbourhood \#2 DZ-12 & 12 & 27 & 15 & $0(-)$ & 380: low-rise / walk-up \\
\hline Neighbourhood \#2 DZ-8 & 8 & 57 & 21 & $1(0)$ & 380: low-rise / walk-up \\
\hline Total Neighbourhood \#3 & Mean 5.6 ${ }^{b}$ & Total 579 & 246 & $4(3)$ & \\
\hline Neighbourhood \#3 DZ-1 & 1 & 55 & 21 & $1(1)$ & 330: low-rise / walk-up \\
\hline Neighbourhood \#3 DZ-2 & 2 & 102 & 40 & $1(1)$ & 390: low-rise / walk-up \\
\hline Neighbourhood \#3 DZ-7 & 7 & 30 & 17 & $0(-)$ & 350: low-rise / walk-up \\
\hline Neighbourhood \#3 DZ-11 & 11 & 96 & 34 & $1(0)$ & 220: low-rise \\
\hline Neighbourhood \#3 DZ-4 & 4 & 49 & 20 & $0(-)$ & 210: low-rise \\
\hline Neighbourhood \#3 DZ-3 & 3 & 85 & 52 & $0(-)$ & 290: low-rise / walk-up \\
\hline Neighbourhood \#3 DZ-13 & 13 & 131 & 53 & $1(11)$ & 290: low-rise / walk-up \\
\hline Total Neighbourhood \#4 & Mean 11.0 ${ }^{b}$ & Total 154 & 98 & $3(2)$ & \\
\hline Neighbourhood \#4 DZ-10 & 10 & 48 & 30 & $0(-)$ & 420: low-rise / high-rise \\
\hline Neighbourhood \#4 DZ-6 & 6 & 32 & 24 & $1(1)$ & 400: low-rise / walk-up \\
\hline Neighbourhood \#4 DZ-17 & 17 & 29 & 20 & $0(-)$ & 370: low-rise / high-rise \\
\hline Total Neighbourhood \#5 & Mean 25.7 & Total 137 & 35 & $1(1)$ & \\
\hline Neighbourhood \#5 DZ-25 & 25 & 27 & 6 & $0(-)$ & 300: low-rise / walk-up \\
\hline Neighbourhood \#5 DZ-22 & 22 & 88 & 25 & $0(-)$ & 320: low-rise / walk-up \\
\hline Neighbourhood \#5 DZ-30 & $30^{\mathrm{a}}$ & 17 & 4 & $1(1)$ & 100 : low-rise / walk-up \\
\hline Total Neighbourhood \#6 & Mean 14.5 & Total 89 & 36 & $2(2)$ & \\
\hline Neighbourhood \#6 DZ-14 & 14 & 42 & 13 & $1(1)$ & 440: low-rise / walk-up \\
\hline Neighbourhood \#6 DZ-15 & 15 & 47 & 23 & $1(1)$ & 440: low-rise / walk-up \\
\hline Total Neighbourhood \#7 & Mean 17.7 & Total 93 & 17 & $1(1)$ & \\
\hline Neighbourhood \#7 DZ-19 & 19 & 55 & 6 & $0(-)$ & 300: low-rise \\
\hline Neighbourhood \#7 DZ-16 & 16 & 31 & 10 & $1(1)$ & 350: low-rise \\
\hline Neighbourhood \#7 DZ-18 & 18 & 7 & 1 & $0(-)$ & 310: low-rise \\
\hline Neighbourhood \#8 & Mean 24.5 & Total 29 & 4 & $1(1)$ & \\
\hline Neighbourhood \#8 DZ-28 & 28 & 17 & 1 & $1(1)$ & 340: low-rise / walk-up \\
\hline Neighbourhood \#8 DZ-21 & 21 & 12 & 3 & $0(-)$ & 350: low-rise / walk-up \\
\hline \multicolumn{6}{|l|}{ Shared Data Zones (parts) } \\
\hline Neighbourhood \#2 DZ-5 & 5 & 67 & 31 & $0(-)$ & 160: high-rise \\
\hline Neighbourhood \#4 DZ-5 & 5 & 45 & 24 & $2(1)$ & 360: low-rise / high-rise \\
\hline Neighbourhood \#3 DZ-9 & 9 & 31 & 9 & $0(-)$ & 210: low-rise / walk-up \\
\hline Neighbourhood \#5 DZ-9 & 9 & 5 & 0 & $0(-)$ & 150: low-rise \\
\hline Whole Study Area & - & 1,406 & 589 & $17(13)$ & \\
\hline
\end{tabular}

Notes: ${ }^{a}$ Output area includes some non-surveyed (newer) private housing (excluded from housing total).

${ }^{\mathrm{b}}$ These means exclude Data Zones (D-Z 5 \& 9) which overlap between neighbourhoods. 
Table 2: Predicting detritus from off-sales provision and deprivation

\begin{tabular}{|c|c|c|c|c|c|c|}
\hline Linear regression: & \multicolumn{3}{|c|}{ All detritus $(n=1406)$} & \multicolumn{3}{|c|}{ Glass detritus only $(n=587)$} \\
\hline \multicolumn{7}{|c|}{ Full Model controlling for Data Zone population } \\
\hline Predictors & B & $t$ & $p$ & $\mathrm{~B}$ & $t$ & $p$ \\
\hline Deprivation rank (1-30) & -1.804 & -2.899 & 0.008 & -0.995 & -3.694 & 0.001 \\
\hline Off-sales (dummy coded, $0-1$ ) & 13.542 & 1.201 & 0.241 & 6.383 & 1.308 & 0.202 \\
\hline Total Data Zone Population & -0.035 & -0.741 & 0.546 & -0.011 & -0.536 & 0.597 \\
\hline constant & 97.012 & 2.714 & 0.012 & 41.066 & 2.654 & 0.013 \\
\hline & \multicolumn{3}{|c|}{$\begin{array}{l}\text { Adjusted } \mathrm{R}^{2}=23.2 \% \\
F=3.919, p=0.20\end{array}$} & \multicolumn{3}{|c|}{$\begin{array}{l}\text { Adjusted } \mathrm{R}^{2}=33.2 \% \\
F=5.813, p=0.004\end{array}$} \\
\hline \multicolumn{7}{|c|}{ Model after variable indicating the presence of off-sales outlet removed } \\
\hline Predictors & B & $t$ & $p$ & $\mathrm{~B}$ & $t$ & $p$ \\
\hline Deprivation rank (1-30) & -1.882 & -3.015 & 0.006 & -1.031 & -3.800 & 0.001 \\
\hline Total Data Zone Population & -0.015 & -0.335 & 0.740 & -0.002 & -0.077 & 0.939 \\
\hline constant & 87.984 & 2.498 & 0.019 & 36.811 & 2.402 & 0.023 \\
\hline & \multicolumn{3}{|c|}{$\begin{array}{l}\text { Adjusted } \mathrm{R}^{2}=21.9 \% \\
F=5.075, p=0.13\end{array}$} & \multicolumn{3}{|c|}{$\begin{array}{l}\text { Adjusted } \mathrm{R}^{2}=31.5 \% \\
F=7.663, p=0.02\end{array}$} \\
\hline
\end{tabular}

\begin{tabular}{|c|c|c|c|c|c|c|}
\hline Linear regression: & \multicolumn{3}{|c|}{ All detritus $(n=1406)$} & \multicolumn{3}{|c|}{ Glass detritus only $(n=587)$} \\
\hline \multicolumn{7}{|c|}{ Full Model controlling for precise number of houses surveyed } \\
\hline Predictors & $\mathrm{B}$ & $t$ & $p$ & $\mathrm{~B}$ & $t$ & $p$ \\
\hline Deprivation rank (1-30) & -2.019 & -3.132 & 0.004 & -1.036 & -3.716 & 0.001 \\
\hline Off-sales (dummy coded, 0-1) & 12.102 & 1.092 & 0.285 & 5.546 & 1.157 & 0.258 \\
\hline Houses in area surveyed & -0.036 & -0.477 & 0.638 & -0.002 & -0.065 & 0.948 \\
\hline constant & 84.729 & 2.899 & 0.008 & 33.990 & 2.688 & 0.012 \\
\hline & \multicolumn{3}{|c|}{$\begin{array}{l}\text { Adjusted } \mathrm{R}^{2}=22.2 \% \\
F=3766, p=0.23\end{array}$} & \multicolumn{3}{|c|}{$\begin{array}{l}\text { Adjusted } \mathrm{R}^{2}=32.5 \% \\
F=5.657, p=0.004\end{array}$} \\
\hline \multicolumn{7}{|c|}{ Model after variable indicating the presence of off-sales outlet removed } \\
\hline Predictors & $\mathrm{B}$ & $t$ & $p$ & $\mathrm{~B}$ & $t$ & $p$ \\
\hline Deprivation rank (1-30) & -1.963 & -3.045 & 0.005 & -1.011 & -3.613 & 0.001 \\
\hline Houses in area surveyed & -0.012 & -0.169 & 0.867 & 0.009 & 0.278 & 0.783 \\
\hline constant & 81.313 & 2.788 & 0.010 & 32.425 & 2.563 & 0.016 \\
\hline & \multicolumn{3}{|c|}{$\begin{array}{l}\text { Adjusted } \mathrm{R}^{2}=21.7 \% \\
F=5.017, p=0.14\end{array}$} & \multicolumn{3}{|c|}{$\begin{array}{l}\text { Adjusted } \mathrm{R}^{2}=31.7 \% \\
F=7.719, p=0.02\end{array}$} \\
\hline
\end{tabular}


Figure 1: Neighbourhood \#1 Detritus and Convenience Stores Map

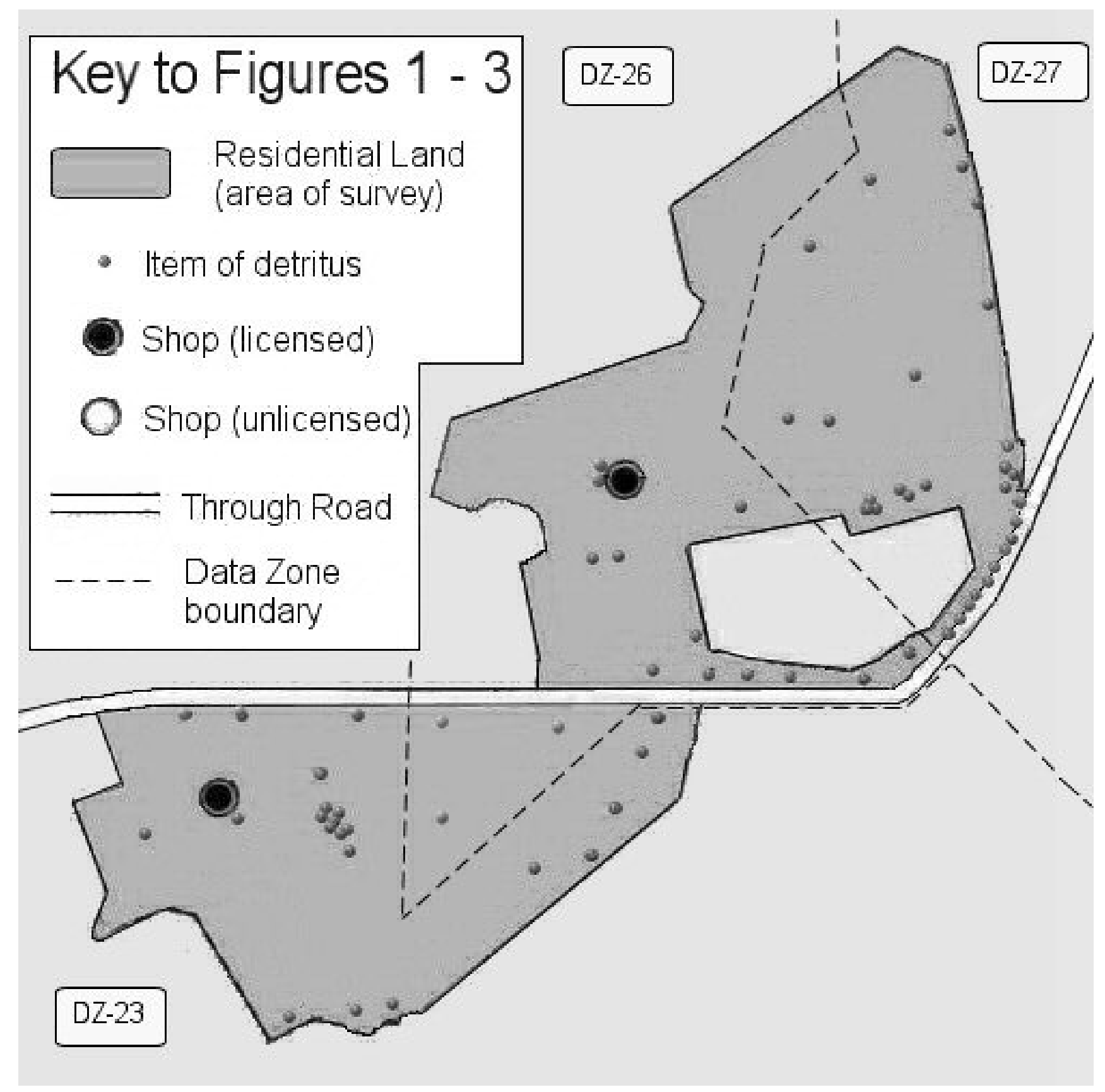


Figure 2: Neighbourhood \#2 Detritus and Convenience Stores Map

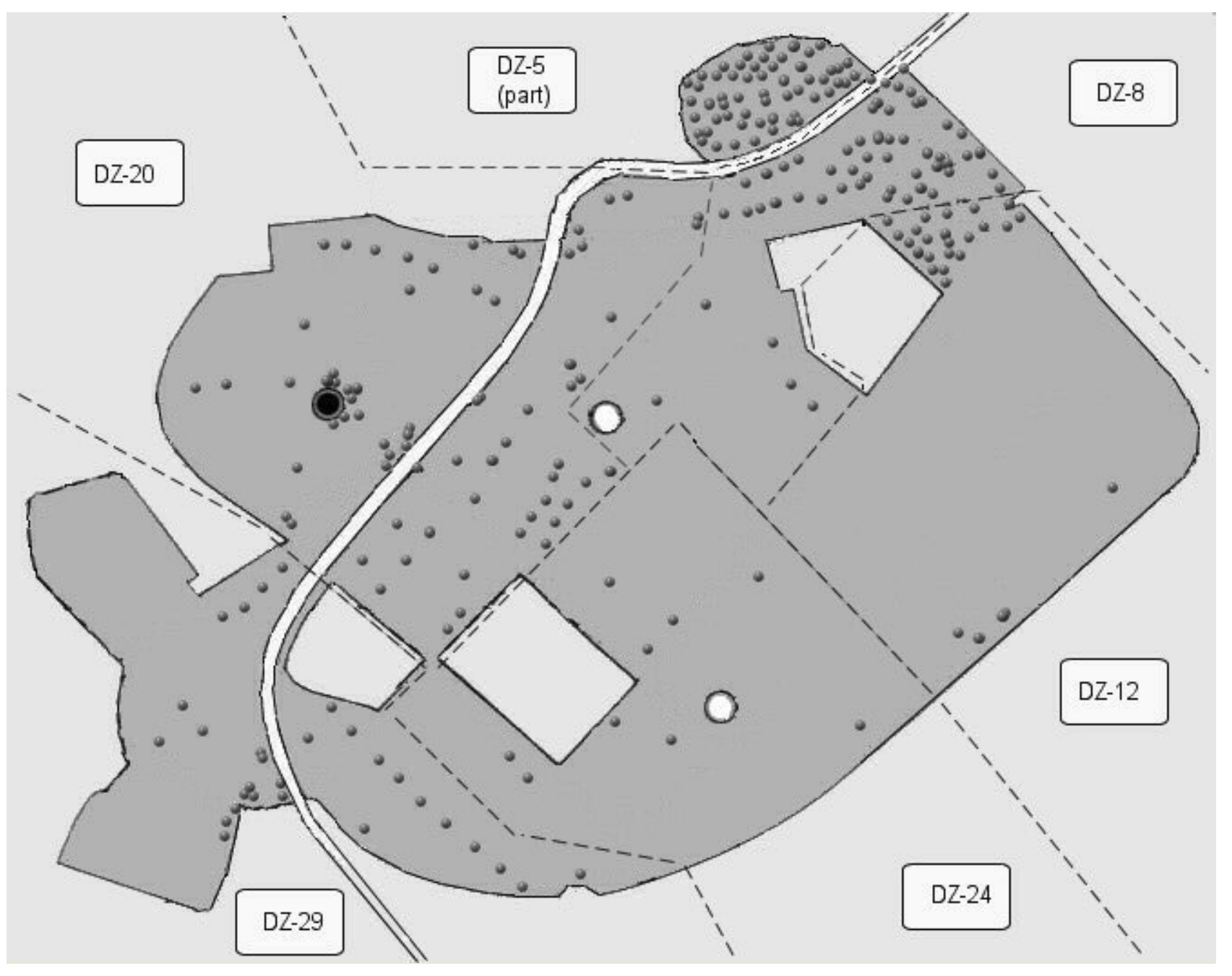


Figure 3: Neighbourhood \#3 Detritus and Convenience Stores Map

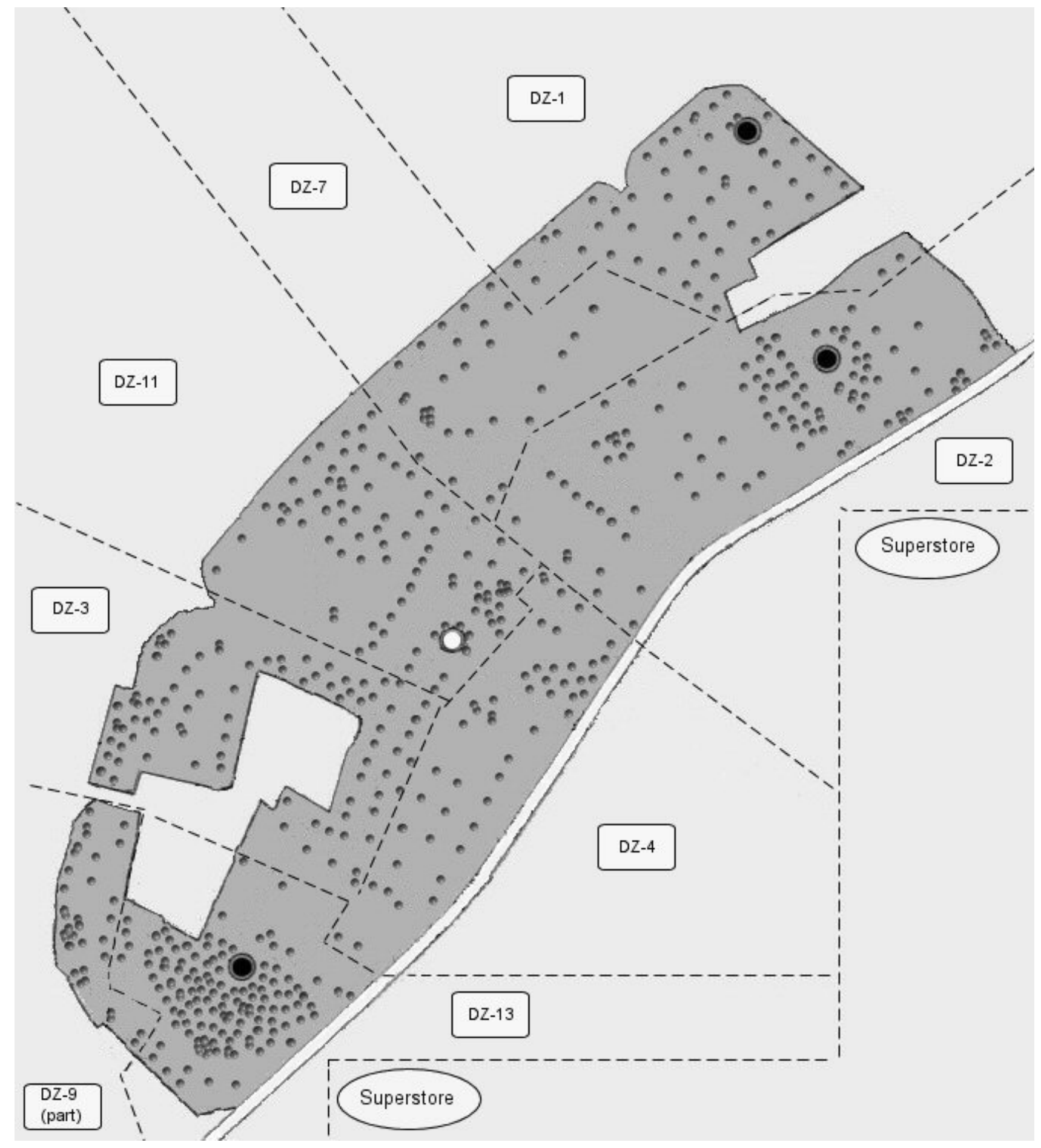


Figure 4: Alcohol-related detritus, area deprivation and convenience stores

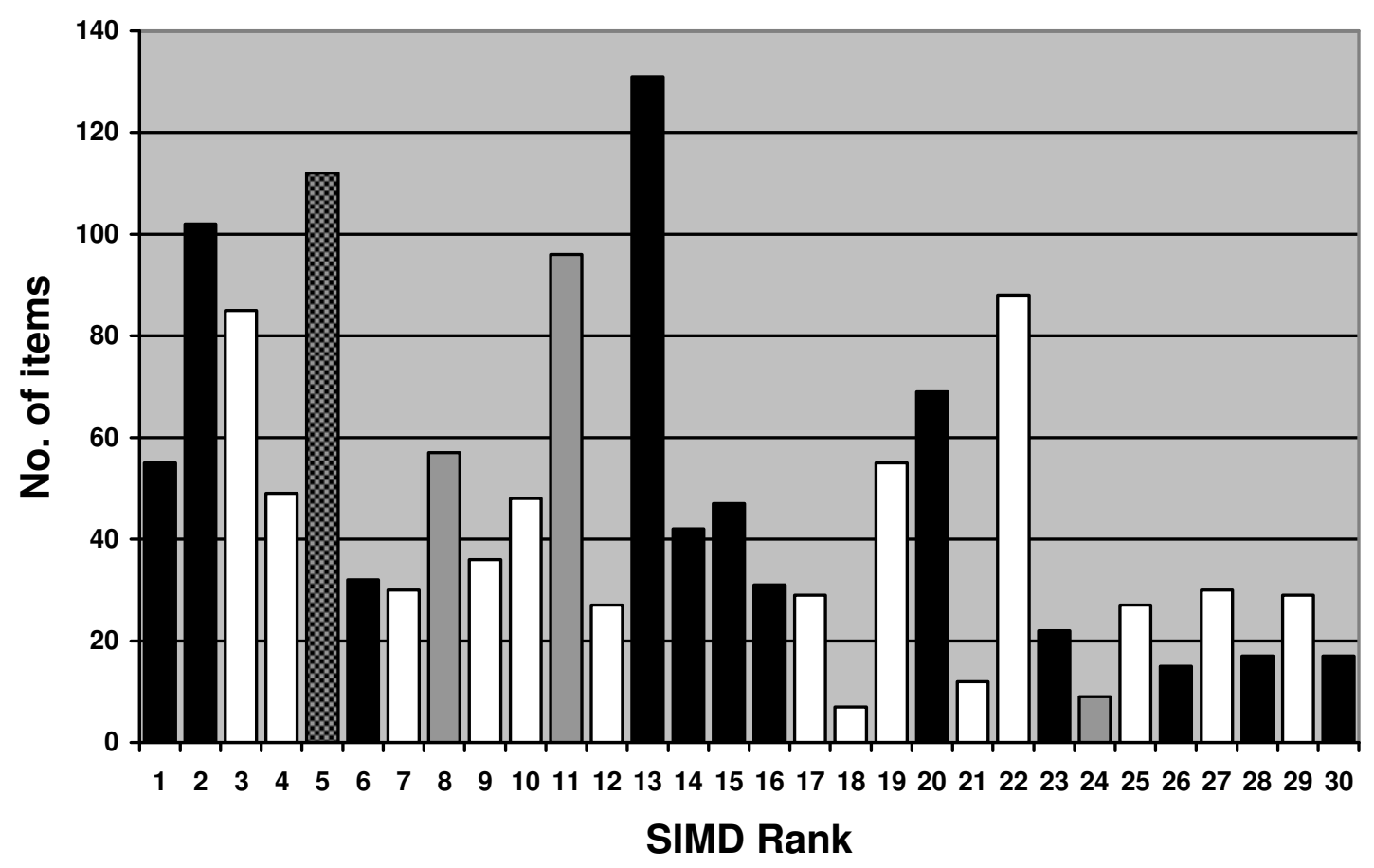

licensed $\square$ unlicensed 圆 both $\square$ no shop 
Figure 5: Branded alcohol glass, area deprivation and convenience stores

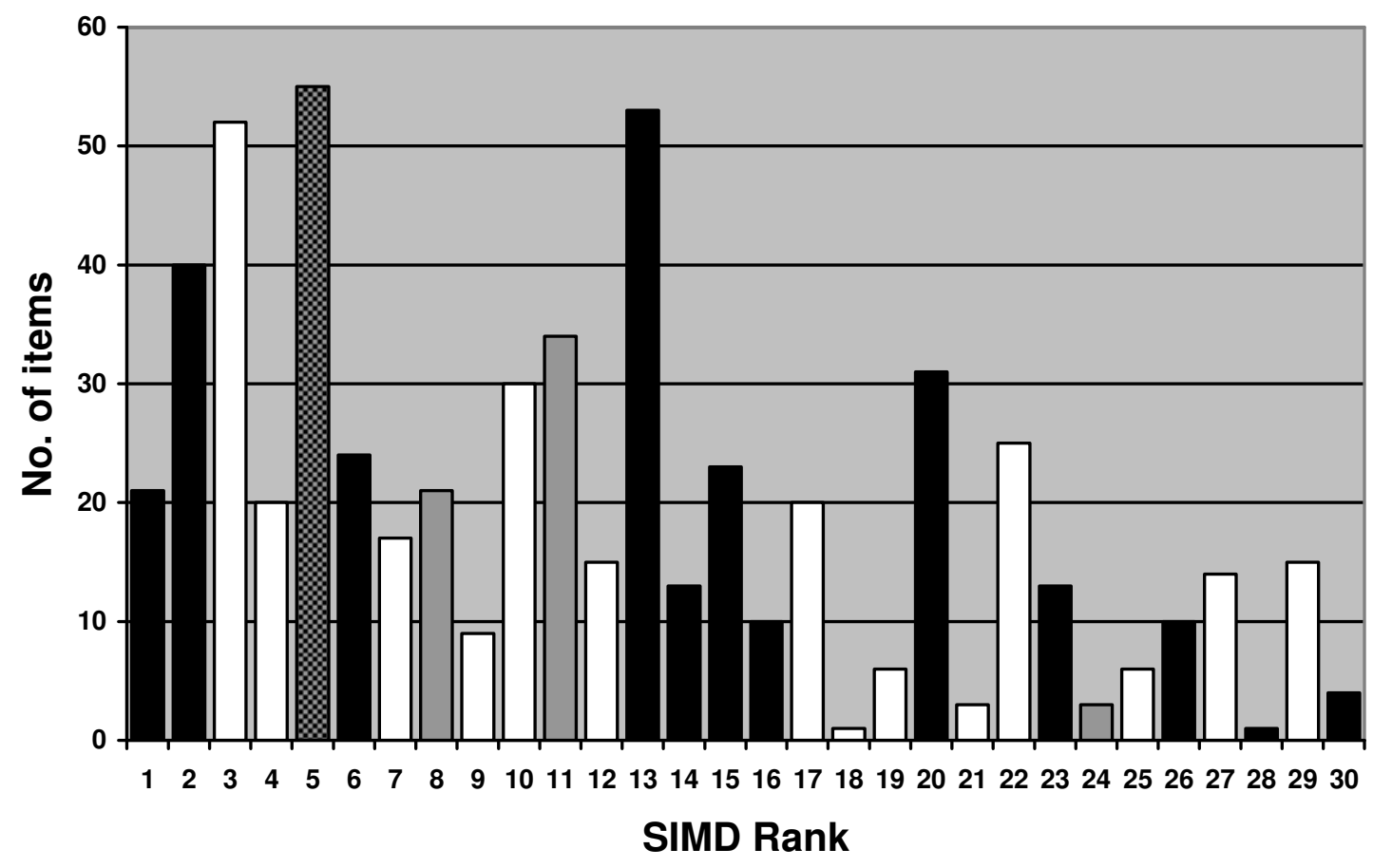

Gicensed $\square$ unlicensed $\mathbf{0}$ both $\square$ no shop 
Plate 1: Alcohol-related Detritus Associated with Superstore Trolley

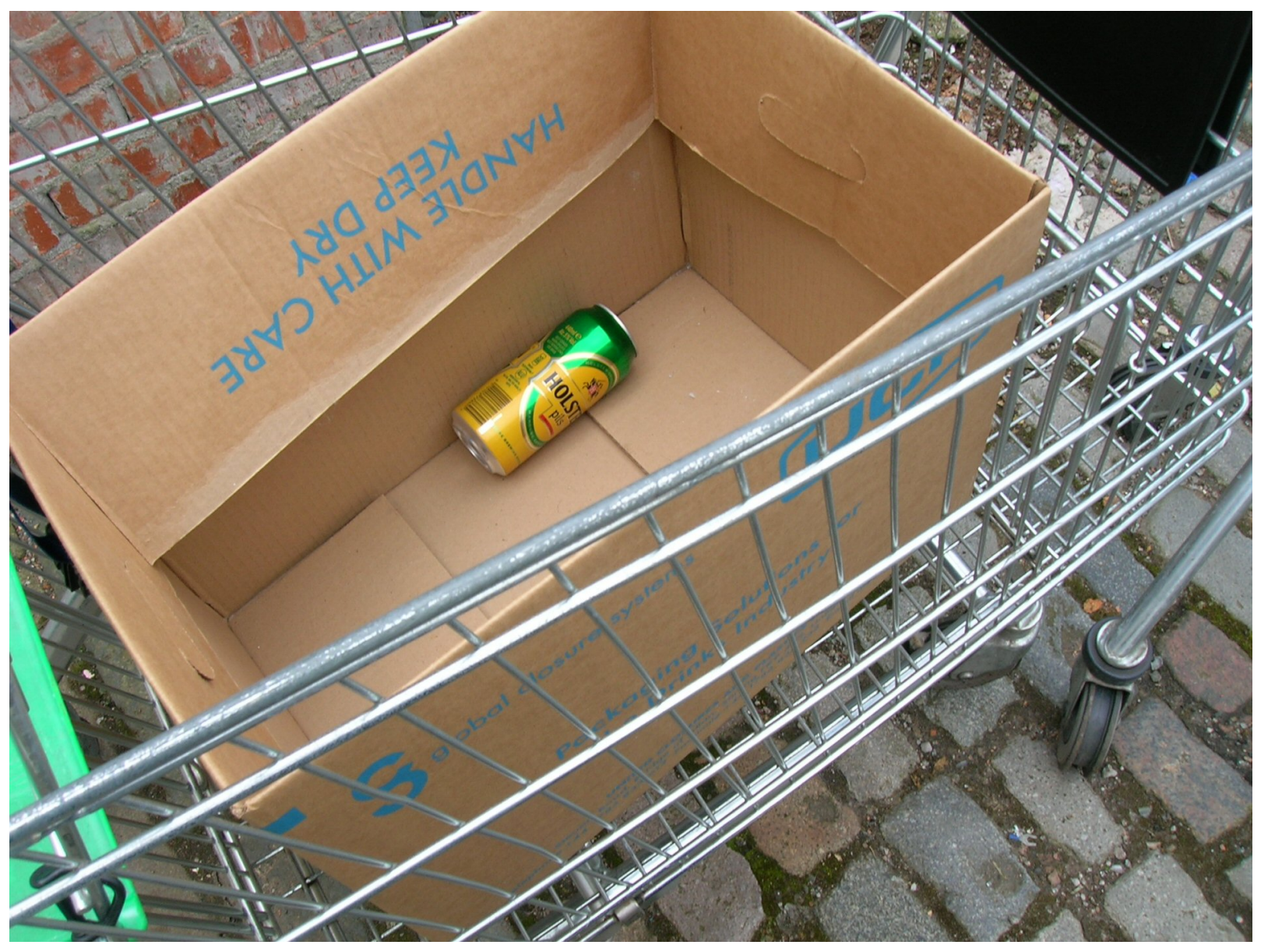


Plate 2: Alcohol-related Detritus Hidden among General Refuse

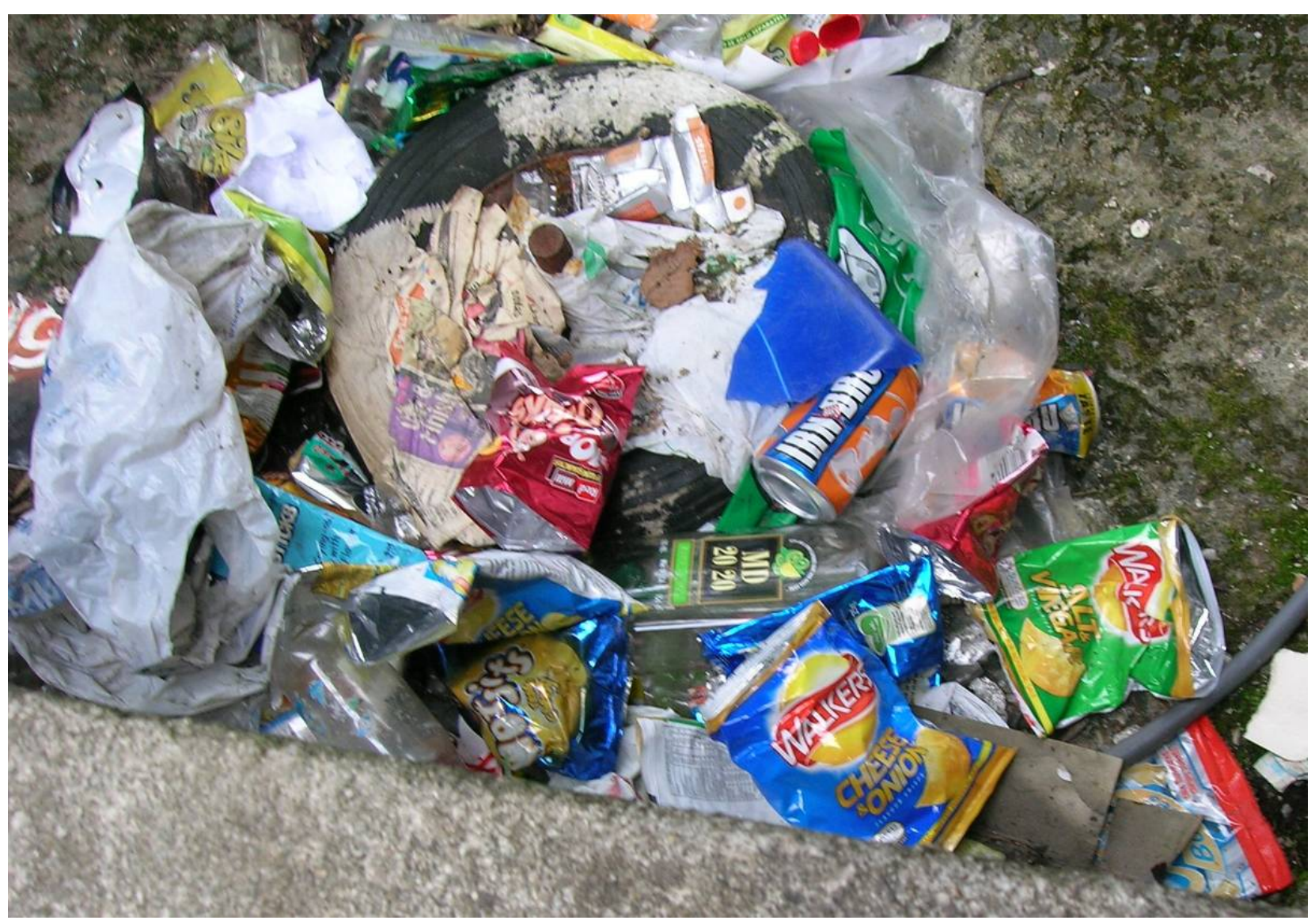

